\title{
Hotel Stock Price Performance During the Covid-19 Pandemic in Indonesia
}

\author{
Regina Sandra Kusuma ${ }^{1}$, Arthik Davianti ${ }^{2}$ \\ 1,2 Satya Wacana Christian University, Salatiga, Indonesia
}

\section{A R T I C L E I N F O}

Article history:

Received 13 January 2021

Received in revised form

15 January 2021

Accepted 18 February 2021

Available online 25

February 2021

Keywords:

Hotel Price, Stock Price, Covid-19

\begin{abstract}
A B S T R A C T
This study aims to analyze the Indonesian hotel stock price performance during the pandemic of Covid-19 by testing the effect of Covid-19 pandemic on stock return and abnormal stock return. The data were collected from secondary data at www.finance.yahoo.com, Indonesian hotel companies stock period from 26 February 2020 to 2 March 2020 during the pandemic of Covid-19. Further, the data were analyzed by using Event Study Methodology to examine the effect of Covid19 pandemic on Indonesian hotel stock return and abnormal return. The result of this study finds that there is stock reaction after the announcement of Covid-19 pandemic in Indonesia during 15 days after the announcement. Also in this research, can be found a relationship between the stock condition with the pandemic. This research can be used as a reference for investors for their investments by looking at the relationship between the Indonesian hotel companies stock and pandemic of Covid-19.
\end{abstract}

\section{Introduction}

Coronavirus is a virus that could cause disease in humans and animals' body (World Health Organization, 2020b). The disease could be fatal and causes death to older people with underlying medical problems. In human bodies, this disease usually interferes with the respiratory systems that can lead into cold and serious illnesses such as MERS (Middle East Respiratory Syndrome) and SARS (Severe Acute Respiratory Syndrome) (Bakar and Rosbi, 2020). As reported by WHO (World Health Organization), COVID-19 has penetrated 216 countries, areas or territories with 6,663,304 cases, and there were 392,802 people who died (World Health Organization, 2020a) infected by this virus. It was first found in human bodies in Wuhan, Hubei Province, China, in December 2019, then it is named SARS-COV2 or Severe Acute Respiratory Syndrome Coronavirus 2 (Djalante et al., 2020).

The impact of the Corona virus pandemic is not only detrimental to the health side it's also affecting the economies of countries around the world, including Indonesia. President Joko Widodo announced that the COVID-19 was confirmed positive in Indonesia on March 2, 2020, (Djalante et al., 2020). Furthermore, the number of Indonesian citizens who have been tested positive for corona virus reached 1,155 and 102 have died (CNN Indonesia, 2020). This virus caused social distancing policies which resulted in corporate offices, financial markets, events and businesses being shut down. Not only that, the exponential rate at spreading of the virus contributed to flight safely in consumption and investment among investors, international trade partners and customer (Ozili \& Arun, 2020). The economic pain became severe as the demand for oil decreased because of travel restrictions imposed during the pandemic, resulted on the declining number of movement goods and people, led to a fall in the demand for aviation fuel, coal and other energy products, which resulted the price of oil decreasing due to lower demand.

The same thing happens in the tourism sector such as hospitality industry, hotel industry was affected primarily by the government's declared 'stay-at-home policy' and government-imposed 'social distancing' command in some countries. To control the spread of coronavirus, this restriction induced shutdowns in cities and counties. Therefore, hotels around the world experienced billions of dollars' cancellations, this industry also sought $\$ 150$ billion bailouts. Many hotels have decided to temporarily close their businesses due to the falling demand. For example, in France hotel occupancy rates decreased 
around 3.3\% on March 17 compared with $65.3 \%$ on February 26 (ILO, 2020). Similar circumstances also occurred in Asian countries, one of them is Indonesia. The occupancy rate of star-rated hotels in Indonesia in March also decreased by $17 \%$ compared to the previous month (in February 49.22\%) (Badan Pusat Statistik, 2020b). In addition, many hotels have laid off thousands of workers permanently or temporarily to keep their businesses afloat.

As the previous arguments Indonesia is not an exception in experiencing a down fall caused by the COVID-19 pandemic, one of industries that has gotten the most negative impact is the tourism sector. Even though the tourism sector has been known as the second largest source of foreign exchange contribution for Indonesia (Soedjatmiko, 2015). Since the instruction to maintain social distance, echo activities at home, and ban on flights between countries since mid-February, the tourism sector experienced a crisis. This could be seen from the number of foreign tourists coming to Indonesia in Quarter I-2020 dropped dramatically by only 2.61 million visits, a decrease of 34.9 percent compared to last year. Besides that, a lot of tourists tend to postpone or cancel their plans to visit tourism sites or even areas that have been indicated with pandemic, especially when people are aware of the dearth of effective drugs and vaccines (Mavondo, 2016). As a result, many tourist sites are closed, occupancy of the majority of hotels also dropped dramatically which means there is no income within a large-scale quarantine, Travel restrictions, and social distance measures encourage a significant decline in consumers and the expenditure of these businesses (Bakar \& Rosbi, 2020).

It is now clear that COVID-19 has a large impact on the tourism industry. This is almost similar (but of a higher magnitude) to what happened to Severe Acute Respiratory Syndrome (SARS) outbreak in 2002-2003 (Strielkowski, 2020). Therefore, this study wants to investigate whether COVID-19 influences the tourism industry especially in the hotel sector, as SARS that according to (Kim et al., 2005) had a very significant effect on the hotel industry. Although the current pandemic phenomenon COVID-19 is very similar to SARS that happened 17 years ago (2003), it is important to remember that the same effect might not necessarily occur. The change of times and technological developments that have influenced people's responses to certain pandemic the effect of both pandemic on hospitality sector could be different in result.

The existence of COVID-19 nowadays has influenced the pattern of our daily lives. Starting from social distancing, appealed to work at home (WFH) for most of the State Civil Apparatus (ASN), eliminate religious activities, and ask people to stay at home and reduce economic activity outside the home. The policy is well-intentioned, but the impact of such policy has a high risk, until the end of March 2020 the government policy is not only social distancing but continued with Physical Distancing, and also the government has set a Large-Scale Social Restrictions (PSBB). Not only that, some trading businesses and world movements have been disrupted because of those prohibitions applied by the government. Most countries began to reduce the production of industrial products and several other important sectors. This outbreak also eventually forced many countries to impose orders not to travel unnecessarily out of the house, especially to travel both inside and outside the country. Even some countries close the travel access such as airports. The hotel business has also been hit hard because the government has implemented a 'home stay policy' where people are suggested to cancel their travel plans that are not important especially for tourist visits. The occupancy rate of star-rated hotels in Indonesia in March also decreased by $17 \%$ from $49.22 \%$ in February (previous month) to 34,24\% (Badan Pusat Statistik, 2020a). Whereas when we compare the pattern that existed in the previous years, the income from the tourism sector from February to March tends to increase or constant that could be seen in the Table 1.

Table 1. Total of Foreign Tourists Comparison 2016 - 2020

\begin{tabular}{|c|c|c|c|c|c|c|c|c|c|}
\hline \multicolumn{2}{|c|}{2020} & \multicolumn{2}{|c|}{2019} & \multicolumn{2}{|c|}{2018} & \multicolumn{2}{|c|}{2017} & \multicolumn{2}{|c|}{2016} \\
\hline February & March & February & March & February & March & February & March & February & March \\
\hline 49,22 & 32,24 & 52,44 & 52,88 & 56,21 & 57,1 & 52,57 & 54,7 & 52,15 & 52,88 \\
\hline \multicolumn{2}{|c|}{$-34 \%$} & \multicolumn{2}{|c|}{$0,83 \%$} & \multicolumn{2}{|c|}{$1,56 \%$} & \multicolumn{2}{|c|}{$3,89 \%$} & \multicolumn{2}{|c|}{$1,38 \%$} \\
\hline
\end{tabular}

From the table above, it can be concluded that in 2020 there was a significant decrease from February to March (-34\%). Meanwhile, if compared to the previous 4 years, there had always been an increase on the total of foreign tourists in Indonesia in a period of February until March. Whereas in 2020 there was a decline due to the occurrence of a COVID-19 which triggered a policy to ban international flights in almost all countries, it did not rule out the possibility of Indonesia being affected by the pandemic from the COVID-19. 
According to the Indonesian Stock Exchange (BEI), there are some star-rated hotels included in the tourism industry. Five of them are: PT Jakarta International Hotels and Development Tbk (Borobudur Hotel), PT Hotel Sahid Jaya International Tbk (Hotel Sahid), PT Satria Mega Kencana Tbk (Lafayette Boutique Hotel), PT Menteng Heritage Realty Tbk (Marriot Hotel), and PT Nusantara Properti Internasional Tbk (Luna2 Hotel). As we all know hotels that have a star-rated based definitely have a good level of public trust, because a good reputation would attract locals and international tourists. Therefore, this study only chooses hotels that are already listed on the Indonesian stock exchange, expecting to reflect the real condition of what happened.

Most of the studies that has been conducted related with the impact of COVID-19 on economics only discussed demands and supply of vacationers and business travels. And most of some other research were focused in other Asian countries such as China (Hoque et al., 2020; Ranasinghe et al., 2020) and international scale (United Nations World Tourism Organisation, 2020). Therefore, this study investigates further to find out the impact of a pandemic to the financial performance of hospitality companies that are particularly available in Indonesia, not only through its influence on tourists or customers in this industry but also on the reaction of its stock market. In addition, because shares are one of the important instruments in evaluating a company, it would be reflected by looking at the movement of stock prices (Sharafoddin \& Emsia, 2016). However, public needs to know that the stock price is influenced by two things, internal and external, one of the external factors is the effect of COVID19 itself on the number of visitors which would result in poor financial reports due to the lack of income, which results in investors who do not trust the report. Stock prices are investors' expectations about future company earnings and dividends (Chen et al., 2012). This study wants to analyse the effect of COVID19 to the stock prices of starrated hotels in Indonesia and to know whether the tourism industry has the biggest fall in total stock values over the month just like SARS outbreak did (Chen et al., 2007). This study aims to analyze the Indonesian hotel stock price performance during the pandemic of Covid-19 by testing the effect of Covid19 pandemic on stock return and abnormal stock return.

\section{Methods}

The research design that will be used in this study is a case study (an event study) which has been widely used to measure the effect of an economic event. The event study of this research aims to describe the problem systematically and factually regarding the impact of the COVID19 outbreak on hotel stock performance in Indonesia. To perform the research and draw conclusions on the results of those studies, quantitative data are required. The importance of the data being analysed can vary based on their diverse existence. Therefore, this research will be using quantitative method. The method of gathering data to obtain quantitative data does not take a long time, and is easy to do.

The data that will be used in this study is secondary data, because of the lack of access to the primary data during this pandemic. The secondary data is sourced from Yahoo Finance. Secondary data is data that has been collected by other parties. This data is collected by investigator agencies and organizations earlier, secondary data is data that relates to the past (Ajayi, 2017). As it is known that in this research the researcher will do an analysis technique by looking at the value of the company's stock prices during COVID19 and before the pandemic occurs. The data about the company's stock price is taken from Yahoo Finance. The reason this study chose Yahoo Finance as a place to retrieve data is because the information about the stock prices contained in Yahoo Finance could be justified. Though Yahoo! Finance isn't a substitute for these kind of databases, it's a useful alternative to make access to financial data easily and quickly (Dicle \& Levendis, 2011).

The secondary data used in this study were obtained from Yahoo Finance website. Because this research uses Time Series data, the estimated stock price is taken during the period of 15 February 2020 17 March 2020 by selecting the closing price of the company's shares. The population of the data used is the hotels whose shares are listed on IDX, are still actively traded on the IDX and the transaction volume is greater than 0 throughout the predetermined period. The sample criteria that will be taken are: a company that has been listed on the IDX in the hotel sector, is still active in stock trading and also in business directly during a predetermined period and also gets a 4 to 5 -star rating service. There are 36 companies engaged in hospitality and their shares have been listed on the IDX and are still actively traded. However, there are only 5 companies that have 4 to 5 -star branch services.

After determining the sample of 5 companies that fit the criteria, stock closing prices in accordance with a predetermined period both in the estimation period and window period are taken. After that the company's share price obtained is equalled by date so that the data processed has equal properties. After doing the equation of the amount of data from the five companies that have been selected, the first step taken is to calculate the actual return in order to find the returns obtained from the 
5 selected sample companies and proceed with the calculation of expected returns during the specified period The next step is to calculate the abnormal return of 5 shares of the selected company with the aim of finding the difference between the actual return and the expected return followed by calculating the abnormal return of stock in order to find out the changes caused by the market response within the specified period.

The population of interest is the target population of the research aimed to examine or treat. Recruitment of the whole population of interest is often not appropriate or feasible in clinical research studies (Majid, 2018). In this study, the population is hotel companies in Indonesia that are specifically listed on the Indonesian stock exchange (BEI). One sample is any part of the population clearly identified (Banerjee \& Chaudhury, 2010). In this study the sample used are non-probability sampling method especially purpose sampling. And the criteria that is suitable for this study is hotel companies in Indonesia that are specifically listed on the Indonesian stock exchange (BEI) that have 5-star rating hotel facilities. In this study the sample used are non-probability sampling method especially purpose sampling. Therefore, this study only chooses hotels that are already listed on the Indonesian stock exchange.

Table 2. Star-Rated Hotel Companies That Listed In BEI

\begin{tabular}{ccl}
\hline No & Code & \multicolumn{1}{c}{ Issuers } \\
\hline 1. & JIHD & PT Jakarta International Hotels and Development Tbk. \\
2. & SHID & PT Hotel Sahid Jaya International Tbk. \\
3. & SOTS & PT Satria Mega Kencana Tbk. \\
4. & HRME & PT Menteng Heritage Realty Tbk. \\
5. & NATO & PT Nusantara Properti Internasional Tbk. \\
\hline
\end{tabular}

Within this case study, the observation period is divided into two, which is window period and estimation time. Event period, event window, or cycle is the time that the event happens and its consequences. But in the other side, the period estimation is the period before the time of the incident (Chandra, 2013). The observant period of the data will be gained by taking daily data from the stock prices of selected company companies that are in yahoo finance during Fabruary 2020 - March 2020, the data taken were in the form of daily data during the period.

Analysis technique that would be done in this study is by taking daily data from the stock prices of selected company companies that are in yahoo finance during 15 Fabruary 2020-15 March 2020 (Last 1 months), the data taken were in the form of daily data during the period. One indicator to measure hotel performance can be seen from the hotel stock price, because the stock price changes every day so it will be easier to analyse the financial performance of the company, besides that the data is easily accessed.

Once the latest information on the financial markets is open, the existing prices are rapidly changing and are prices that reflect the information and conditions as they stand. Abnormal returns are occasionally triggered by "events" (Ratnaningsih \& Widanaputra, 2019). It can be seen from an abnormal return, an announcement containing details would offer an abnormal return back to the market. Abnormal returns or excess returns are the excess returns actually generated against normal returns.

Hypothesis $\mathrm{HO}$ test aimed at investigating the presence of an abnormal return, that may be indicated for the contained information before the announcement of COVID-19 Pandemic in Indonesia by the President of Indonesia and Hypothesis Ha for the reaction after the announcement of COVID-19 Pandemic in Indonesia by the President of Indonesia. The hypothesis is tested with the hypothesis criteria with one-sample t-test, i.e. if Sig 0.05 is accepted, H0 is accepted.

\section{Results and Discussions}

\section{Descriptive Statistics Stock Return}

Descriptive statistics are used to find out the maximum, minimum, and standard deviation of data. Descriptive statistics in this study can be seen in Table 1 until Table 10.

Table 3. Stock Return Before the Announcement (-15 day)

\begin{tabular}{cccc}
\hline Stock & Minimum & Maximum & Standard Deviation \\
\hline NATO & -0.036363 & 0.037735 & 0.020796 \\
HRME & -0.010582 & 0.043956 & 0.016264 \\
SOTS & -0.033898 & 0.271929 & 0.086367 \\
SHID & -0.199134 & 0.062162 & 0.068021
\end{tabular}




\begin{tabular}{cccc}
\hline Stock & Minimum & Maximum & Standard Deviation \\
\hline JIHD & -0.045454 & 0 & 0.014354 \\
\hline
\end{tabular}

Table 3. shows that the maximum stock return of NATO before the president Jokowi announcement about COVID-19 in Indonesia is 0.037735 and the standard deviation of NATO is 0.020796 . Meanwhile, the maximum of the HRME variable is 0.043956 and its standard deviation is 0.016264 . Then, the maximum of the SOTS variable is 0.271929 and its standard deviation is 0.086367 . The maximum for the SHID variable is 0.062162 and its standard deviation is 0.068021 and the maximum of the JIHD variable is 0 and its standard deviation is 0.014354 .

Table 4. Stock Return After the Announcement (+15 day)

\begin{tabular}{cccc}
\hline Stock & Minimum & Maximum & Standard Deviation \\
\hline NATO & -0.008695 & 0.063106 & 0.020656 \\
HRME & -0.052083 & 0.048913 & 0.023934 \\
SOTS & -0.111111 & 0.092592 & 0.053619 \\
SHID & 0 & 0.006535 & 0.001970 \\
JIHD & -0.094827 & 0.047619 & 0.037011 \\
\hline
\end{tabular}

Table 4. shows that the maximum stock return of NATO after the president Jokowi announcement about COVID-19 in Indonesia is 0.063106 and the standard deviation of NATO is 0.020656 . Meanwhile, the maximum of the HRME variable is 0.048913 and its standard deviation is 0.023934 . Then, the maximum of the SOTS variable is 0.092592 and its standard deviation is 0.053619 . The maximum for the SHID variable is 0.006535 and its standard deviation is 0.001970 and the maximum of the JIHD variable is 0.047619 and its standard deviation is 0.037011 .

Table 5. Expected Stock Return Before the Announcement (-15 day)

\begin{tabular}{cccc}
\hline Stock & Minimum & Maximum & Standard Deviation \\
\hline NATO & -0.001212 & 0.001257 & 0.000693 \\
HRME & -0.000352 & 0.001465 & 0.000542 \\
SOTS & -0.001129 & 0.009064 & 0.002878 \\
SHID & -0.006637 & 0.002072 & 0.002267 \\
JIHD & -0.001515 & 0 & 0.000478 \\
\hline
\end{tabular}

Table 5. shows that the maximum expected stock return of NATO before the president Jokowi announcement about COVID-19 in Indonesia is 0.001257 and the standard deviation of NATO is 0.000693 . Meanwhile, the maximum of the HRME variable is 0.001465 and its standard deviation is 0.000542 . Then, the maximum of the SOTS variable is 0.009064 and its standard deviation is 0.002878 . The maximum for the SHID variable is 0.002072 and its standard deviation is 0.002267 and the maximum of the JIHD variable is 0 and its standard deviation is 0.000478 .

Table 6. Expected Stock Return After the Announcement (+15 day)

\begin{tabular}{cccc}
\hline Stock & Minimum & Maximum & Standard Deviation \\
\hline NATO & -0.000289 & 0.00210 & 0.000688 \\
HRME & -0.001736 & 0.001630 & 0.000797 \\
SOTS & -0.003703 & 0.00308 & 0.001787 \\
SHID & 0 & 0.000217 & $6.56 \mathrm{E}-05$ \\
JIHD & -0.00316 & 0.001587 & 0.001233 \\
\hline
\end{tabular}

Table 6. shows that the maximum expected stock return of NATO after the president Jokowi announcement about COVID-19 in Indonesia is 0.00210 and the standard deviation of NATO is 0.000688 . Meanwhile, the maximum of the HRME variable is 0.001630 and its standard deviation is 0.000797 . Then, the maximum of the SOTS variable is 0.00308 and its standard deviation is 0.001787 . The maximum for the SHID variable is 0.000217 and its standard deviation is $6.56 \mathrm{E}-05$ and the maximum of the JIHD variable is 0.001587 and its standard deviation is 0.001233 .

Table 7. Abnormal Stock Return Before the Announcement (-15 day) 


\begin{tabular}{cccc}
\hline Stock & Minimum & Maximum & Standard Deviation \\
\hline NATO & -0.035151 & 0.036477 & 0.020103 \\
HRME & -0.010229 & 0.042490 & 0.015722 \\
SOTS & -0.032768 & 0.262865 & 0.08348 \\
SHID & -0.192496 & 0.06009 & 0.065754 \\
JIHD & -0.043939 & 0 & 0.01387 \\
\hline
\end{tabular}

Table 7 shows that the maximum abnormal stock return of NATO before the president Jokowi announcement about COVID-19 in Indonesia is 0.036477 and the standard deviation of NATO is 0.020103. Meanwhile, the maximum of the HRME variable is 0.042490 and its standard deviation is 0.015722 . Then, the maximum of the SOTS variable is 0.262865 and its standard deviation is 0.08348 . The maximum for the SHID variable is 0.06009 and its standard deviation is 0.065754 and the maximum of the JIHD variable is 0 and its standard deviation is 0.01387 .

Table 8. Abnormal Stock Return After the Announcement (+15 day)

\begin{tabular}{cccc}
\hline Stock & Minimum & Maximum & Standard Deviation \\
\hline NATO & -0.008405 & 0.061003 & 0.019967 \\
HRME & -0.050347 & 0.047282 & 0.023136 \\
SOTS & -0.107407 & 0.089506 & 0.05183 \\
SHID & 0 & 0.006318 & 0.001904 \\
JIHD & -0.091666 & 0.046031 & 0.035777 \\
\hline
\end{tabular}

Table 8. shows that the maximum abnormal stock return of NATO after the president Jokowi announcement about COVID-19 in Indonesia is 0.061003 and the standard deviation of NATO is 0.019967 . Meanwhile, the maximum of the HRME variable is 0.047282 and its standard deviation is 0.023136 . Then, the maximum of the SOTS variable is 0.089506 and its standard deviation is 0.05183 . The maximum for the SHID variable is 0.006318 and its standard deviation is 0.001904 and the maximum of the JIHD variable is 0.046031 and its standard deviation is 0.035777 .

Table 9. Average Abnormal Stock Return Before the Announcement (-15 day)

\begin{tabular}{cccc}
\hline Stock & Minimum & Maximum & Standard Deviation \\
\hline NATO & -0.001171 & 0.001215 & 0.000670 \\
HRME & -0.000340 & 0.001416 & 0.000524 \\
SOTS & -0.001092 & 0.008762 & 0.002782 \\
SHID & -0.006416 & 0.002003 & 0.002191 \\
JIHD & -0.001464 & 0 & 0.000462 \\
\hline
\end{tabular}

Table 9. shows that the maximum average abnormal stock return of NATO before the president Jokowi announcement about COVID-19 in Indonesia is 0.001215 and the standard deviation of NATO is 0.000670. Meanwhile, the maximum of the HRME variable is 0.001416 and its standard deviation is 0.000524 . Then, the maximum of the SOTS variable is 0.008762 and its standard deviation is 0.002782 . The maximum for the SHID variable is 0.002003 and its standard deviation is 0.002191 and the maximum of the JIHD variable is 0 and its standard deviation is 0.000462 .

Table 10. Average Abnormal Stock Return After the Announcement (+15 day)

\begin{tabular}{cccc}
\hline Stock & Minimum & Maximum & Standard Deviation \\
\hline NATO & -0.000280 & 0.002033 & 0.000665 \\
HRME & -0.001678 & 0.001576 & 0.000771 \\
SOTS & -0.003580 & 0.002983 & 0.00172 \\
SHID & 0 & 0.000210 & $6.34 \mathrm{E}-05$ \\
JHHD & -0.003055 & 0.001534 & 0.001192 \\
\hline
\end{tabular}

Table 10. shows that the maximum average abnormal stock return of NATO after the president Jokowi announcement about COVID-19 in Indonesia is 0.002033 and the standard deviation of NATO is 0.000665 . Meanwhile, the maximum of the HRME variable is 0.001576 and its standard deviation is 
0.000771. Then, the maximum of the SOTS variable is 0.002983 and its standard deviation is 0.00172 . The maximum for the SHID variable is 0.000210 and its standard deviation is $6.34 \mathrm{E}-05$ and the maximum of the JIHD variable is 0.001534 and its standard deviation is 0.001192 .

\section{One Sample T-Test Result}

Following the previous result, the data that already obtained will perform a one sample T-Test. The one sample T-Test is to determine if the null hypothesis should be rejected with 0.05 significant values is used in this study to do the normality test.

Table 11. Normality Test of Abnormal Stock Return

\begin{tabular}{ccccccc}
\hline & \multicolumn{3}{c}{ Kolmogorov-Smirnova $^{\mathbf{a}}$} & \multicolumn{3}{c}{ Shapiro-Wilk } \\
\cline { 2 - 7 } & Statistic & df & Sig. & Statistic & df & Sig. \\
\hline NATO & .230 & 22 & .004 & .904 & 22 & .036 \\
HRME & .196 & 22 & .027 & .897 & 22 & .026 \\
SOTS & .292 & 22 & .000 & .740 & 22 & .000 \\
SHID & .507 & 22 & .000 & .349 & 22 & .000 \\
JIHD & .383 & 22 & .000 & .673 & 22 & .000 \\
\hline
\end{tabular}

Table 11 shows that all the data is not normally distribute because of the significant level lower than 0.05 .

Table 12. One-Sample Test of Abnormal Stock Return

\begin{tabular}{|c|c|c|c|c|c|c|}
\hline & \multicolumn{6}{|c|}{ Test Value $=-0.199134$} \\
\hline & \multirow[b]{2}{*}{$\mathbf{t}$} & \multirow[b]{2}{*}{ df } & \multirow{2}{*}{$\begin{array}{l}\text { Sig. (2- } \\
\text { tailed) }\end{array}$} & \multirow[b]{2}{*}{ Mean Difference } & \multicolumn{2}{|c|}{$\begin{array}{l}\text { 95\% Confidence Interval of the } \\
\text { Difference }\end{array}$} \\
\hline & & & & & Lower & Upper \\
\hline NATO & 45.322 & 21 & .000 & .203819982 & .19446764 & .21317232 \\
\hline HRME & 44.932 & 21 & .000 & .198186515 & .18901369 & .20735934 \\
\hline SOTS & 14.093 & 21 & .000 & .210831753 & .17972100 & .24194250 \\
\hline SHID & 20.790 & 21 & .000 & .193402717 & .17405636 & .21274907 \\
\hline JIHD & 34.914 & 21 & .000 & .197837251 & .18605326 & .20962125 \\
\hline
\end{tabular}

Table 12 shows that the significant level of all stock are lower than 0.05 significant levels. The author assumes that all the data are normally distribute. According to the result, hypothesis $\mathrm{HO}$ is rejected.

\section{Discussion}

According to the developed hypothesis, the result shows that $\mathrm{H}_{1}$ accepted. The analysis indicates that there is stock reaction after the announcement of COVID-19 Pandemic in Indonesia by the President of Indonesia. From the policy that create by government, it gives a huge impact for the tourism industry especially hotel industry and from the data that tested, mostly all the hotel doing business on tourist area. From the one sample T-Test, the result shows that the significant level of all Indonesian Hotel abnormal stock return is 0.000 which mean lower than the 0.05 significant level. However, the author assumes that the data used on the one sample T-Test are normally distribute. The stock reaction happened after the announcement by President of Indonesia, some province declares a lockdown or Large-scale Social Restrictions (PSBB) to avoid the spread of the COVID-19 on their area. The result of this study was supported by Chen et al. (2007) that explain SARS pandemic have a negative effect towards Taiwanese hotel abnormal returns and have an effect towards Taiwanese hotel stocks performance. Another study by Strielkowski (2020) found that COVID-19 pandemic have an effect towards tourism industry and have a higher magnitude rather than the previous SARS pandemic and Hoque et al. (2020) studies which explain that the three are stock reaction after a COVID-19 and SARS pandemic. Based on the study by Elad and Bongbee (2017), Chen et al. (2007), Strielkowski (2020) and Hoque et al. (2020) shows an event study methodology is a relevant method to explain the effect of pandemic to the stock market that concentrated on share price behaviour during the event or pandemic.

The existence of COVID-19 nowadays has influenced the pattern of our daily lives. Starting from social distancing, appealed to work at home (WFH) for most of the State Civil Apparatus (ASN), eliminate religious activities, and ask people to stay at home and reduce economic activity outside the home. The policy is well-intentioned, but the impact of such policy has a high risk, until the end of March 2020 the 
government policy is not only social distancing but continued with Physical Distancing, and also the government has set a Large-Scale Social Restrictions (PSBB). Not only that, some trading businesses and world movements have been disrupted because of those prohibitions applied by the government. Most countries began to reduce the production of industrial products and several other important sectors. This outbreak also eventually forced many countries to impose orders not to travel unnecessarily out of the house, especially to travel both inside and outside the country. Even some countries close the travel access such as airports. The hotel business has also been hit hard because the government has implemented a 'home stay policy' where people are suggested to cancel their travel plans that are not important especially for tourist visits.

\section{Conclusion}

From this study, the author aims to find out if theirs is a stock reaction before the announcement of COVID-19 pandemic in Indonesia. The result of this study finds that there is stock reaction after the announcement of COVID-19 pandemic in Indonesia during 15 days after the announcement. Also in this research, can be found a relationship between the stock condition with the pandemic. This research is a study on the stock reaction because of the pandemic COVID-19. The author used the daily data during the pandemic of COVID-19 from 17 February 2020 to 17 March 2020. Further research is recommended to use the period before pandemic COVID-19 and the beginning period of COVID-19 pandemic until the end of the pandemic. So, it can obtain more findings in detail about the reaction of Hotel Stock toward COVID19 pandemic.

This examination might be valuable as a kind of perspective for the speculators to observe the Indonesian hotel companies' stock during the pandemic of COVID-19. It ought to be considered since the hotel companies' stock has a relationship with the tourism industry that got the most effect by COVID-19 pandemic, additionally. For the traders of investors in stock market, the author suggests that traders and investors must be aware of the state of health in daily life that give an impact on the stock condition, and prepare trading or investment strategies to follow the market situation and to be able to achieve the goal of an investment.

\section{References}

Ajayi, V. O. (2017). Primary Sources of Data and Secondary Sources of Data. (September), 1-6. https://doi.org/10.13140/RG.2.2.24292.68481.

Badan Pusat Statistik. (2020a). Jumlah Kunjungan Wisman Menurut Kebangsaan dan Bulan Kedatangan Tahun 2017 - 2020. Retrieved from www.bps.go.id website: https://www.bps.go.id/dynamictable/2018/07/30/1548/jumlah-kunjungan-wisman-menurutkebangsaan-dan-bulan-kedatangan-tahun-2017---2020.html.

Badan Pusat Statistik. (2020b). Tingkat Penghunian Kamar pada Hotel Bintang di Indonesia, 2008 - 2020. Retrieved June 7, 2020, from www.bps.go.id website: https://www.bps.go.id/linkTableDinamis/view/id/980.

Bakar, N. A., \& Rosbi, S. (2020). Effect of Coronavirus disease (COVID-19) to tourism industry. International Journal of Advanced Engineering Research and Science, 7(4), 189-193. https://doi.org/10.22161/ijaers.74.23.

Banerjee, A., \& Chaudhury, S. (2010). Statistics without tears: Populations and samples. Industrial Psychiatry Journal, 19(1), 60. https://doi.org/10.4103/0972-6748.77642.

Chandra, T. (2013). the Impact of Fuel Price Increase on Stock Price in Indonesia Stock Exchange. Journal of Economics, Business, and Accountancy / Ventura, 16(3), 385. https://doi.org/10.14414/jebav.v16i3.219.

Chen, M. H., Agrusa, J., Krumwiede, D., \& Lu, H. J. (2012). Macroeconomic Influences On Japanese Hotel Stock Returns. Journal of Hospitality Marketing and Management, 21(1), 81-99. https://doi.org/10.1080/19368623.2011.611731.

Chen, M. H., Jang, S. C. (Shawn), \& Kim, W. G. (2007). The impact of the SARS outbreak on Taiwanese hotel stock performance: An event-study approach. International Journal of Hospitality Management, 26(1), 200-212. https://doi.org/10.1016/j.ijhm.2005.11.004. 
CNN Indonesia. (2020). Update Corona 28 Maret: 1.155 Kasus, 102 Meninggal, 59 Sembuh. Retrieved June 6, 2020, from www.cnnindonesia.com website: https://www.cnnindonesia.com/nasional/20200328125504-20-487797/update-corona-28maret-1155-kasus-102-meninggal-59-sembuh.

Dicle, M. F., \& Levendis, J. (2011). Importing Financial Data. The Stata Journal: Promoting Communications on Statistics and Stata, 11(4), 620-626. https://doi.org/10.1177/1536867x1201100408.

Djalante, R., Lassa, J., Setiamarga, D., Sudjatma, A., Indrawan, M., Haryanto, B., ... Warsilah, H. (2020). Review and analysis of current responses to COVID-19 in Indonesia: Period of January to March $\begin{array}{lllll}\text { 2020. } & \text { Progress } & & \end{array}$ https://doi.org/10.1016/j.pdisas.2020.100091.

Hoque, A., Shikha, F. A., Hasanat, M. W., Arif, I., \& Abu Bakar Abdul Hamid. (2020). The Effect of Coronavirus (COVID-19) in the Tourism Industry in China. Asian Journal of Multidisciplinary Studies, 3(1).

Kim, S. S., Chun, H., \& Lee, H. (2005). The effects of SARS on the Korean hotel industry and measures to overcome the crisis: A case study of six Korean five-star hotels. Asia Pacific Journal of Tourism Research, 10(4), 369-377. https://doi.org/10.1080/10941660500363694.

Majid, U. (2018). Research Fundamentals: Study Design, Population, and Sample Size. Undergraduate Research in Natural and Clinical Science and Technology (URNCST) Journal, 2(1), 1-7. https://doi.org/10.26685/urncst.16.

Mavondo, F. (2016). Mavondo, F. T. and Reisinger, Y. (February 2005). " Travel Anxiety and Intentions to Travel Internationally: Implications of Travel Risk Perception " has been published in the Journa ... (April).

Ozili, P. K., \& Arun, T. (2020). Spillover of COVID-19: Impact on the Global Economy. SSRN Electronic Journal, (March). https://doi.org/10.2139/ssrn.3562570.

Ranasinghe, R., Damunupola, A., Wijesundara, S., Karunarathna, C., Nawarathna, D., Gamage, S., ... Idroos, A. A. (2020). Tourism after Corona: Impacts of Covid 19 Pandemic and Way Forward for Tourism, Hotel and Mice Industry in Sri Lanka SSRN Electronic Journal, (April). https://doi.org/10.2139/ssrn.3587170.

Ratnaningsih, N. M. D., \& Widanaputra, A. A. G. P. (2019). The reaction of Indonesian capital market to political event the announcement of Indonesia presidential election 2019 results. International Research Journal of Management, IT and Social Sciences, 6(6), 87-94. https://doi.org/10.21744/irjmis.v6n6.765.

Sharafoddin, S., \& Emsia, E. (2016). The Effect of Stock Valuation on the Company's Management. Procedia Economics and Finance, 36(16), 128-136. https://doi.org/10.1016/s2212-5671(16)30024-7.

Soedjatmiko. (2015). Sports Tourism Development in Indonesia. Journal of Sports Science, 3(5). https://doi.org/10.17265/2332-7839/2015.08.009.

Strielkowski, W. (2020). COVID-19 recovery strategy for tourism industry COVID-19 recovery strategy for tourism industry. (March), 1-3. https://doi.org/10.13140/RG.2.2.19039.82086.

World Health Organization. (2020a). Coronavirus disease (COVID-19) outbreak situation. Retrieved June 6, 2020, from www.who.int website: https://www.who.int/emergencies/diseases/novelcoronavirus-2019.

World Health Organization. (2020b). What is Coronavirus? Retrieved June 6, 2020, from www.who.int website: https://www.who.int/emergencies/diseases/novel-coronavirus-2019/coronavirusdisease-answers?query=What+is+COVID19\%3F. 